\title{
The history of exploration and stratigraphy of the Early to Middle Triassic vertebrate-bearing strata of Svalbard (Sassendalen Group, Spitsbergen)
}

\author{
Jørn H. Hurum', Victoria S. Engelschiøn ${ }^{3,1}$, Inghild $\varnothing \mathrm{kland}^{\prime}$, Janne Bratvold', \\ Christina P. Ekeheien', Aubrey J. Roberts',2, Lene L. Delsett', Bitten B. Hansen', \\ Atle Mørk ${ }^{3}$, Hans A. Nakrem ${ }^{1}$, Patrick S. Druckenmiller ${ }^{4} \&$ Øyvind Hammer ${ }^{1}$ \\ ${ }^{1}$ Natural History Museum, P.O. Box 1172 Blindern, NO-0318 Oslo, Norway. \\ ${ }^{2}$ The Natural History Museum, Earth Sciences, Cromwell Road, London SW7 5BD, UK. \\ ${ }^{3}$ Department of Geoscience and Petroleum, Norwegian University of Sciences and Technology, NO-7491 Trondheim, Norway. \\ ${ }^{4}$ University of Alaska Museum and Department of Geology and Geophysics, University of Alaska Fairbanks, 907 Yukon Dr., Fairbanks, Alaska, 99775, \\ USA.
}

E-mail corresponding author (Jørn H. Hurum): j.h.hurum@nhm.uio.no

\begin{abstract}
The palaeontology of the Lower to Middle Triassic succession in Spitsbergen has been studied for more than a century and a half. Our ability to properly interpret the evolutionary and ecological implications of the faunas requires precise stratigraphic control that has only recently become available. Within such a detailed stratigraphic framework, the Spitsbergen fossil material promises to contribute to our understanding of the faunal recovery after the end-Permian mass extinction.
\end{abstract}

Keywords: Triassic stratigraphy, Boreal, Spitsbergen, Svalbard, Ichthyopterygia, Sedimentology, Mass extinction, Marmierfjellet, Vikinghøgda, Deltadalen, Botneheia, Olenekian, Anisian, Smithian, Spathian

\section{Introduction}

The Permian-Triassic Mass Extinction (PTME) was by far the largest extinction in Earth's history, during which a staggering $90 \%$ of all species living in marine habitats are thought to have become extinct (Raup \& Sepkoski, 1982; Erwin, 1994; Benton, 1995; Wignall et al., 1998; Scheyer et al., 2014; Roopnarine \& Angielczyk, 2015). The mass extinction also affected life in terrestrial habitats, where approximately $70 \%$ of all vertebrates disappeared (Elewa, 2008; Metcalfe \& Isozaki, 2009; Yin \& Song, 2013). The extinction has been proposed to be caused by an increase in volcanic eruptions during the Late Permian, which reached its peak during the waning stages of the Palaeozoic (Burgess et al., 2017). A direct result of this was the formation of the Siberian Traps (Yin \& Song, 2013; Burgess et al., 2017). As a result of escalating volcanic activity, vast amounts of gas was released into the atmosphere (Burgess et al., 2017), creating a heating effect that contributed to a warmer global climate (Yin \& Song, 2013). Intense heating during the final phases of the Permian may very well have been one of, if not the most dominant, causes for the mass extinction (Hallam \& Wignall, 1997). The recovery stages in the wake of the end Permian extinctions resulted in the evolution of new Triassic marine communities, some of which still dominate today's oceans (Erwin, 1998).

During the Early Triassic, Svalbard formed part of a large

Hurum, J.H., Engelschiøn, V.S., Økland, I., Bratvold, J., Ekeheien, C.P., Roberts, A.J., Delsett, L.L., Hansen, B.B., Mørk, A., Nakrem, H.A., Druckenmiller, P.S. \& Hammer, Ø. 2018: The history of exploration and stratigraphy of the Early to Middle Triassic vertebrate-bearing strata of Svalbard (Sassendalen Group, Spitsbergen). Norwegian Journal of Geology 98, 165-174. https://dx.doi.org/10.17850/njg98-2-04. 
embayment on the northern margin of Pangaea, known as the Boreal Ocean, although it was at approximately $45^{\circ}$ palaeolatitude, or just north of the modern Mediterranean Sea if we compare to the present-day map (Nystuen et al., 2013; Lundschien et al., 2014). Located in the northern regions of Panthalassa, it connected Eurasia/Baltica in the east with Laurentia/Gondwana in the west (Mørk, 2015). Recent excavations in what is today South China and Nevada have revealed extensive evidence of the biotic recovery after the PTME, with certain localities even preserving several ecosystems over millions of years (see Benton et al., 2013; Motani et al., 2014; Jiang et al., 2016; Kelley et al., 2016; Brayard et al., 2017). However, much less is known about this biotic recovery in other areas. The fossiliferous Early to Middle Triassic successions in Svalbard are one of the best, yet understudied localities to document and interpret the survival and recovery of marine ecosystems in the Boreal realm (Foster et al., 2016) with a crucial placement between the Chinese and Nevada localities.

Of special interest are several clades of tetrapods that evolved secondary aquatic lifestyles in the Triassic. Notably, Ichthyosauriformes is traditionally recognised as one of the clades originating and diversifying shortly after the PTME, during the Early Triassic (Smithian; e.g., Massare \& Callaway, 1994; Sander, 2000; Motani, 2005; Motani et al., 2014; Jiang et al., 2016). Our current understanding of ecosystem recovery post-PTME is limited, but the new excavations from the Early and Middle Triassic of Svalbard, described in this volume, are increasing our knowledge of taxonomic diversity, niche partitioning and cladogenesis post-PTME.

\section{Early work (1864-1964)}

Ichthyopterygian material has been collected and described from the Triassic strata of Svalbard since the late 19th century (Nordenskiöld, 1866; Hulke, 1873; Dames, 1895; Yakowlew, 1903). These collections were undertaken during the first scientific expeditions to map the geology of Svalbard; but the stratigraphic resolution was poor. As a result, none of the specimens collected from Spitsbergen in the nineteenth century can be placed in a more modern stratigraphic context with any certainty.

In 1908, the student Bertil Högbom participated in geologist De Geer's expedition to the Isfjorden area of central Spitsbergen on behalf of Swedish palaeontologist Carl Wiman. The expedition was a success, with a large amount of material collected. As a result, in 1909, Wiman instigated an expedition from Uppsala University, Sweden, led by Högbom, during which substantial amounts of ichthyopterygian material were collected from central Spitsbergen (Wiman, 1910a). In the following decades, Wiman published a series of papers on the ichthyopterygian remains from this area
(Wiman, 1916a, 1922, 1928, 1933). Smaller expeditions to Spitsbergen were also organised to collect Triassic vertebrates in the summers of 1912, 1913, 1915 and 1916-1918, but these expeditions mostly focused on Triassic fish and stegocephalians (Wiman, 1910b, 1914a, b, 1916b, 1917, 1918; Stensiö, 1918, 1921, 1925).

Wiman (1910a) described the Triassic strata around Isfjorden with three main vertebrate-bearing horizons placed according to the biostratigraphy as defined by Noetling (1905). A horizon rich in fossil fish, 'das Fischniveau' $(=$ the Fish niveau $=$ the Fish horizon of Wiman (1916a)) and two ichthyopterygian bonebearing and stratigraphically restricted levels, 'das unteres Saurierniveau' (= Lower Saurian niveau $=$ the Lower Saurian horizon of Wiman (1916a)) and 'das oberes Saurierniveau' ( $=$ the Upper Saurian niveau $=$ the Upper Saurian horizon of Wiman (1916a)). The Fish niveau correlates to the Posidonomya shales, and the Upper Saurian niveau was correlated to the upper part of the 'Daonellen-niveau' as defined by Mojsisovics (1886). During the following decades, many workers adopted the biostratigraphic nomenclature of Wiman (1910a, 1916a) (e.g., Stolley, 1911; Böhm, 1912; Diener, 1916; Stensiö, 1918, 1921; Spath, 1921, 1934; Frebold, 1930). Stensiö (1921) located a bone-bearing level of 'rather local nature' $33 \mathrm{~m}$ above the Fish niveau (he used the term 'horizon'), containing chondrichthyans, parasuchians, unrecognisable tetrapod material and ichthyopterygians, and Omphalosaurus. The bone-bearing level also contained ammonoids and was assumed to be an endemic fauna (Frebold, 1930).

In 1928, Wiman described Grippia longirostris Wiman, 1928, based on material collected by the Hamburg Spitsbergen Expedition during fieldwork on the east side of Spitsbergen in 1927. Based on information from palaeontologist E. Stensiö and based on "the iron-rich matrix surrounding the specimen", a 'Grippia niveau' was interpreted to exist somewhere between the Fish niveau and the Lower Saurian niveau (Wiman, 1928). Further expeditions were carried out in 1929 and 1930, and a concretion-rich layer interpreted as the Grippia niveau was found in Agardhbukta and on Milne Edwardsfjellet on Spitsbergen (Wiman, 1933).

\section{Recent work (1965-present)}

The Triassic stratigraphy of Spitsbergen as defined by Wiman remained the main framework for all subsequent workers until Buchan et al. (1965) revised the lithostratigraphy of central Spitsbergen, but they also commented on other areas of Svalbard. Using the scheme of Buchan et al. (1965), Tozer \& Parker (1968) subsequently updated the Triassic biostratigraphy of Svalbard. Several revisions were later made by other workers studying the lithostratigraphy of Svalbard that also combined invertebrate, microfossil and palynological 
data collected from additional localities (Birkenmajer, 1977 - Sørkapp Land; Lock et al., 1978 - Barentsøya and Edgeøya; Worsley \& Mørk, 1978 - Sørkapp Land; Pčelina, 1980, 1983 - entire Svalbard; Mørk et al., 1982 - Svalbard, 1990 - Bjørnøya, 1999a - entire Svalbard, 1999b Spitsbergen, Barentsøya and Edgeøya; Weitschat \& Dagys, 1989 - Svalbard; Krajewski et al., 2007 - Western Svalbard; Krajewski, 2008 - Barentsøya and Edgeøya; Nakrem et al., 2008 - Spitsbergen; Vigran et al., 2014 Svalbard). Few attempts were made to correlate the older biostratigraphic scheme of Wiman with the modern, revised, lithostratigraphic studies until recently (Maxwell \& Kear, 2013). As a result, much of the vertebrate material that had been collected from the Lower to Middle Triassic of Svalbard has now been roughly placed in the stratigraphic context defined by Wiman (1910a). However, much of this vertebrate material has not been placed with any accuracy in detailed stratigraphic logs from the different localities (e.g., Mazin, 1981a, b, 1983, Maisch \& Matzke, 2002b, 2003a, b). An example of difficulties arising from a lack of stratigraphic control is the supposedly articulated ichthyosaur specimen of Merriamosaurus hulkei (a junior synonym to Pessopteryx nisseri, see discussion in Engelschiøn et al., 2018). The material was collected in the 1960s by the Muséum National d'Histoire Naturelle (MNHN) in Paris, from various localities (e.g., Heimenfjellet and Ibsenfjella, approximately $4.5 \mathrm{~km}$ apart). Maisch \& Matzke (2002b) assigned a significant amount of material to $M$. hulkei claiming it to represent one individual due to the similar size and type of preservation. Ultimately, more than 170 fragments, or two-thirds of the total material, was reassembled and assigned to a single specimen (Maisch \& Matzke, 2002b).

Early Triassic ichthyopterygians from Svalbard have received sporadic attention in the latter half of the 20th century. Collections were made by the Cambridge Spitsbergen Expeditions during geological expeditions in 1948-1992 (= the Cambridge Arctic Shelf Programme (CASP) since 1975). Much of the material housed in the CASP collection in Cambridge, and material donated by, or bought from private collectors in the Natural History Museum in London remains undescribed. The Muséum National d'Histoire Naturelle (MNHN) in Paris conducted two expeditions to Spitsbergen; the 1964 Lehman-MNHN expedition and the 1969 CNRSMNHN expedition (Centre National de la Recherche Scientifique). The focus of these expeditions was on Palaeozoic and Triassic fish, although ichthyopterygian remains were also collected. Mazin published a series of papers on the MNHN material (Mazin, 1981a, b, 1983, 1984), later revised by Maisch \& Matzke (Maisch \& Matzke, 2002a, b, 2003a, b). Maisch \& Blomeier (2009) described a Middle Triassic ?toretocnemid collected in Dickson Land by geologists from the Norwegian Polar Institute in 2003. In 2008, scientists from the Norwegian Petroleum Directorate and the Natural History Museum in Oslo collected a Middle Triassic mixosaurid specimen from Edgeøya, one of the eastern islands in the Svalbard archipelago (Hurum et al., 2014). In summary, the material collected by Wiman has formed the basis for our understanding of Triassic vertebrates from Svalbard until today, although much of the material has been repeatedly redescribed, and many specimens are now considered non-diagnostic (for a review see Sander \& Faber, 1998; Motani, 1999; Maxwell \& Kear, 2013).

\section{The work by the Spitsbergen Mesozoic Research Group at the Natural History Museum in Oslo (2014-now)}

During three seasons of fieldwork in 2014-16, abundant vertebrate material has been recovered from the Lower and Middle Triassic Sassendalen Group (Vikinghøgda and Botneheia formations) in the Isfjorden area of central Spitsbergen. The newly collected material discussed below is from the Lower and Middle Triassic deposits of Marmierfjellet, central Spitsbergen, Svalbard (Fig. 1). The material is housed in the Natural History Museum, University of Oslo (collection prefix PMO). All localities are denominated by their approved name by the Norwegian Polar Institute, and all necessary permits were obtained from the Governor of Svalbard for the excavations; permits no. RiS 6725, 2013/1222-2; RiS 10227, 2015/00326-2; and RiS 10539, 2015/00326-5. The following papers (Bratvold et al., 2018; Ekeheien et al., 2018; Engelschiøn et al., 2018; Hansen et al., 2018; Økland et al., 2018) in this volume will highlight some of the early findings from the vast material still being processed at the museum in Oslo.

\section{Geological setting}

During the Triassic, a large embayment of the Panthalassa Ocean was located on the northern rim of Pangaea, known as the Boreal Ocean (Nystuen et al., 2013; Lundschien et al., 2014). At a palaeolatitude of approximately $45^{\circ} \mathrm{N}$, the Boreal Ocean formed a lowrelief, open-marine shelf, surrounded by Eurasia/Baltica and the Urals to the east and southeast, and the North American portion of Gondwana/Laurentia to the west, including Greenland to the southwest and the Canadian Arctic islands to the northwest (Mørk, 2015). During the Permian, Siberia moved towards Euramerica and eventually closed the Uralian Seaway that connected the Boreal Ocean to the equatorial Tethys, leading to the creation of the Uralian Mountains (Worsley, 2008; Lundschien et al., 2014; Blomeier, 2015). The coastline in the Early Triassic was mainly located outside of presentday Svalbard, with sediment input originating from the southwest. Later, northeast-prograding clinoforms 


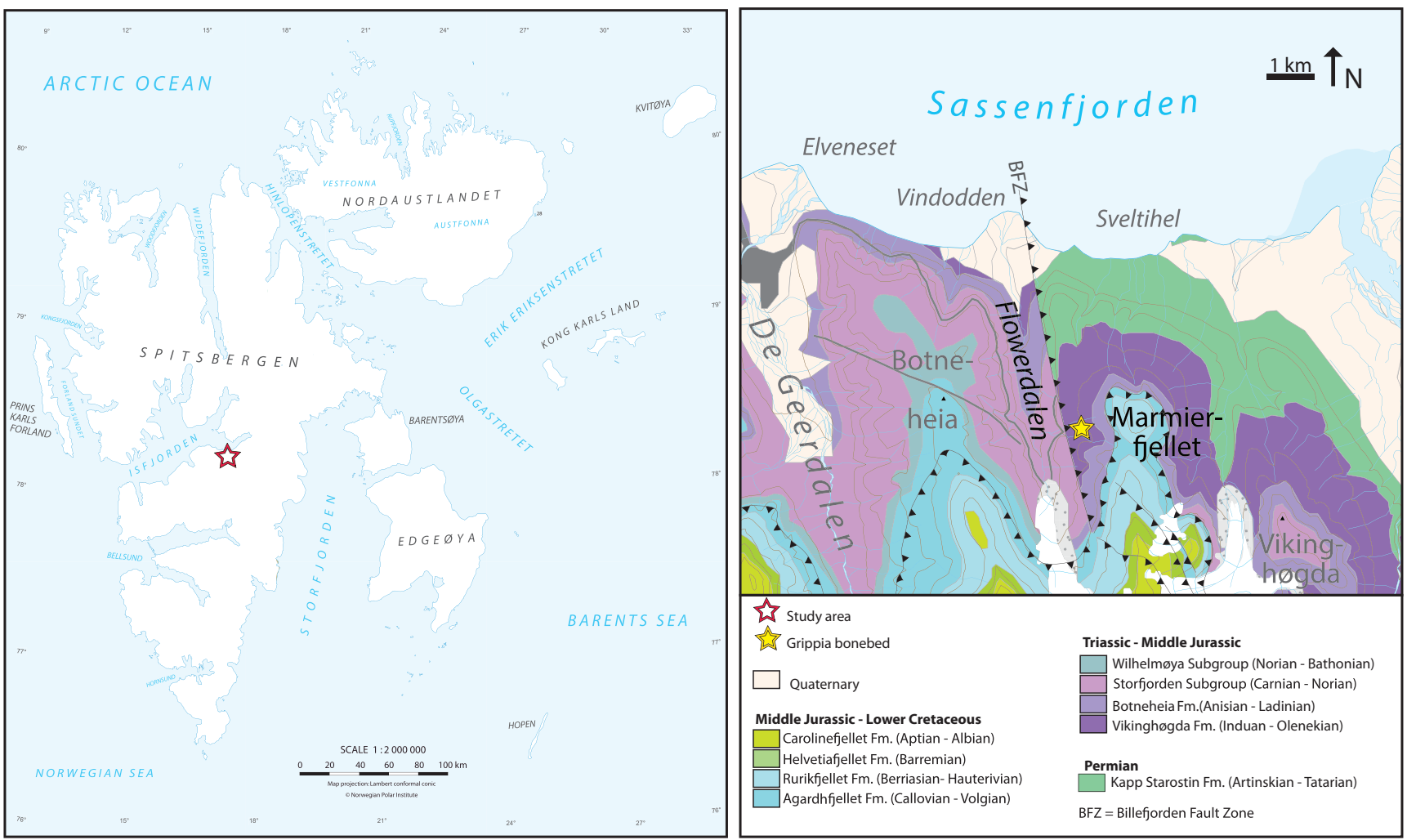

Figure 1. Overview map of the Mesozoic rocks in the study area. Modified from Dallmann (2015).

from the denudation of the Ural Mountains reached the Svalbard archipelago during the Carnian (Riis et al., 2008; Worsley, 2008). Climatic changes following the Uralian orogeny were substantial, as evidenced by drastic changes in the lithology of units deposited during this interval, beginning with spiculitic shales of the Permian Kapp Starostin Formation (Tempelfjorden Group) and changing to the fine siliciclastics of the Sassendalen Group (Vigran et al., 2014). This has been termed the 'Early Triassic silica gap' by Beauchamp \& Baud (2002). The geology of Svalbard reflects the regional depositional environment of the Barents Sea Continental Shelf in the Triassic. The main sediment supply was from the southwest resulting in a coastal to basinal depositional environment (Vigran et al., 2014). As such, the Middle Triassic sequences of Western Spitsbergen are characterised by coastal and shallow-marine sandstones and shales, whereas Central and Eastern Spitsbergen, Edgeøya and Barentsøya consist of shales and siltstones from a deeper basin (Mørk et al., 1999a; Hounslow et al., 2008a, b).

\section{The uppermost Permian to Middle Triassic} Sassendalen Group, Central-Eastern Spitsbergen

The Sassendalen Group was first defined by Buchan et al. (1965) and is still maintained today (Mørk et al., 1999a). Buchan et al. (1965) recognised three lithostratigraphic units: a shallow-marine to coastal silt- and sandstone unit, a middle unit of upward-coarsening shale-siltstone strata and an upper unit of phosphatic and organic-rich shales, which were named the Vardebukta, Sticky Keep and Botneheia formations, respectively. Mørk et al. (1999a, b) refined the stratigraphy within the Sassendalen Group in southern and western areas of Spitsbergen to comprise the Vardebukta, Tvillingodden and Bravaisberget formations, while the central and eastern parts consist of the Vikinghøgda and Botneheia formations. The Vikinghøgda Formation is the eastern equivalent of the Vardebukta and Tvillingodden formations of western Spitsbergen, whereas the Botneheia Formation is a distal equivalent of the Bravaisberget Formation (Mørk et al., 1999b).

The Sassendalen Group in central-eastern Spitsbergen is characterised by three upward-shallowing sequences in the two formations (the Vikinghøgda Fm. and the Botneheia Fm.).

\section{Vikinghøgda Formation}

The Vikinghøgda Formation represents a shallowmarine shelf environment with storm deposits, situated east of the deltaic coast environment of Western Spitsbergen (Mørk et al., 1999b; Vigran et al., 2014). The formation consists of grey, silty shales with yellowweathering siltstone beds generated by storm events (Mørk et al., 1982). Beneath the Vikinghøgda Formation 
is the Permian, chert-rich, Kapp Starostin Formation, and it is overlain by the Botneheia Formation, comprising mostly dark organic rich, calcareous shales of marine origin (Mørk et al., 1999a, b). The Vikinghøgda Formation is divided into three members; the Deltadalen Member consists of mudstones with sandstones and siltstones, the Lusitaniadalen Member is characterised by silty mudstones with limestone concretions, and the Vendomdalen Member comprises darker silty shales (Mørk et al., 1999b). The Vikinghøgda Formation spans the Upper Permian Changhsingian Stage to the boundary between the Lower Triassic Olenekian Stage and the Middle Triassic Anisian Stage. The basal few metres of the formation are composed of a sandstone or mudstone gradually grading into a mudstone with thin siltstone or sandstone beds, interpreted as transgressive units (Mørk et al., 1999b). With a total thickness is $250 \mathrm{~m}$ (Mørk et al., 1999b), the Vikinghøgda Formation is well exposed at the type section in Sassendalen, including exposures on the mountains of Vikinghøgda and Sticky Keep and the river valley Deltadalen between the. The uppermost part, the Vendomdalen Member, is also well exposed in the study area on the hillside of Marmierfjellet in Flowerdalen, immediately west of Sassendalen.

Ammonoids, bivalves, brachiopods and vertebrates occur in discrete horizons throughout the Vikinghøgda Formation, along with carbonate concretions (Mørk et al., 1999b). The biostratigraphy of the Vikinghøgda Formation has been defined by ammonoids, conodonts and palynology, with the ammonoid stratigraphy of W. Weitschat providing crucial age control (Weitschat \& Lehmann, 1978; Weitschat \& Dagys, 1989; Dagys \& Weitschat, 1993; Mørk et al., 1999b). Tozer (1994), Dagys \& Sobolev (1995) and Piazza et al. (2017) continued this work and Hounslow et al. (2008a) linked the magnetostratigraphy of the Vikinghøgda Formation to the ammonoid biostratigraphy. The palynological composite assemblage zones were defined by Mørk et al. (1999b) and Vigran et al. (2014).

\section{Deltadalen Member}

The Deltadalen Member extends from the upper Changhsingian through most of the Induan and is well constrained by a biostratigraphy of ammonoids and conodonts, and magnetostratigraphy (Mørk et al., 1999b; Hounslow et al., 2008a; Nakrem et al., 2008).

Nakrem et al. (2008) suggested that the Permian/Triassic boundary occurs between 5 and $11 \mathrm{~m}$ above the base of the Deltadalen Member. This was based on the conodont Neogonodlella carinata, indicative of a Griesbachian age. The disappearance of bioturbation in the same interval is a good indicator for the boundary in the field (Foster et al., 2016). The basal few metres are composed of bedded, glauconitic sandstones that are very similar to those in the underlying Kapp Starostin Formation, but the layers lack diagenetic chert nodules (Mørk et al., 1999a, b; Nabbefeld et al., 2010). These sandstones are described by
Nabbefeld et al. (2010) and Foster et al. (2016) to contain a diverse trace fossil assemblage. The sandstones mark the onset of a marine transgression (Mørk et al., 1999b; Nabbefeld et al., 2010). Above the glauconitic sandstone, silty mudstones indicate a significant deepening of the basin. The mudstones were deposited under anoxic and euxinic conditions, and Nabbefeld et al. (2010) found evidence of phytoplankton blooms in this part of the Deltadalen Member. Foster et al. (2016) described the oldest silicified invertebrate assemblage known from the Triassic from two carbonate concretions at 11.9 and 12.6 $\mathrm{m}$ above the base of the member. After acid treatment they were found to contain 14 species of bivalves and gastropods, as well as conodonts and ammonoids. Above the mudstone a greater proportion of siltstones and fine sandstones are interpreted as a progradation or a fall of sea level (Foster et al., 2016). The bioturbation shows a slow recovery with deposition under more oxygenated conditions.

\section{Lusitaniadalen Member}

The Lusitaniadalen Member of the Vikinghøgda Formation is situated above the Deltadalen Member and below the Vendomdalen Member (Fig. 2). The member consists mainly of dark-grey silty mudstones to sandstones, with carbonate concretions especially in the middle and upper parts of the unit. It is $88 \mathrm{~m}$ thick in the type section (Mørk et al., 1999b), but the lower part is generally scree covered. Of special interest regarding vertebrate fossils is the uppermost interval in the member, loosely referred to as the 'Fish niveau' following e.g., Wiman (1918) and Stensiö $(1921,1925)$. The Fish niveau contains abundant calcite concretions with well preserved ammonoids, bivalves, fishes and stegocephalian amphibians. Sedimentology and palynology (Mørk et al., 1999b) indicate a moderately deep shelf environment but closer to the sediment source than the overlying Vendomdalen Member. The base of the Fish niveau has never been formally designated, but the vertebrate remains are typically concentrated within the uppermost $10 \mathrm{~m}$ of the Lusitaniadalen Member.

The Fish niveau is well constrained biostratigraphically by the rich ammonoid fauna (Weitschat \& Lehmann, 1978; Weitschat \& Dagys, 1989; Dagys \& Weitschat, 1993; Mørk et al., 1999b). The lower part belongs to the Euflemingites romunderi Zone of Smithian (early Olenekian) age, while the uppermost 3-4 m contain abundant ammonoids of the Wasatchites tardus Zone, late Smithian. The Smithian-Spathian boundary is marked by a positive carbon isotope excursion that is recognised globally, and provides an excellent chemostratigraphic marker in Spitsbergen (Galfetti et al., 2007). The peak of this excursion is found a few metres above the top of the Lusitaniadalen Member, placing the Fish niveau entirely within the Smithian. 


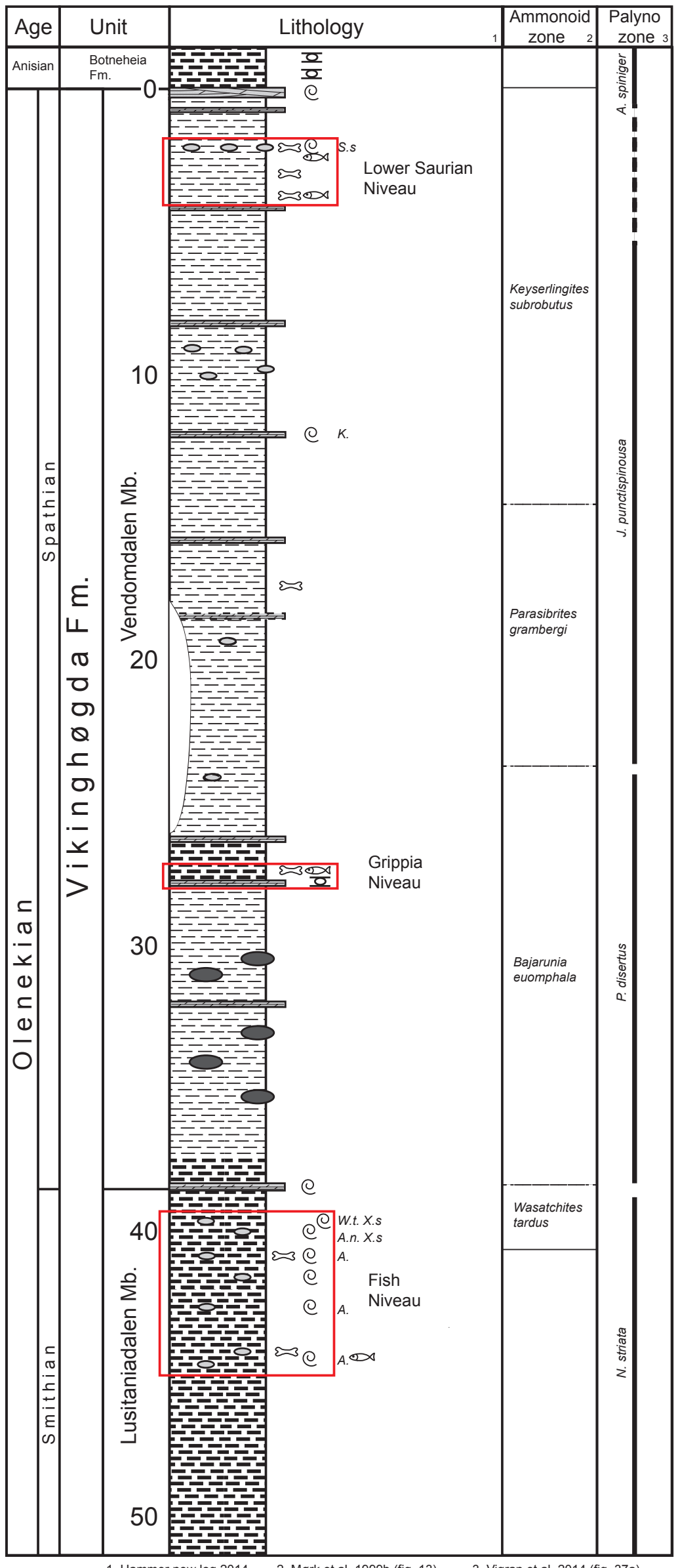

Legend

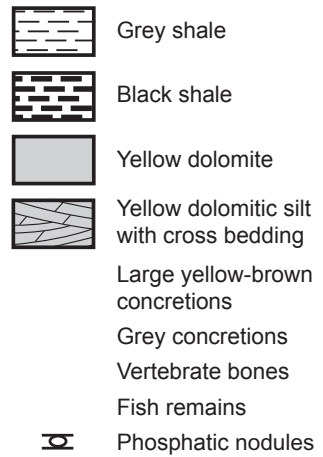

Ammonoids

A. Arctoceras

A.n. Arctoprionites nodusus

K. Keyserlingites

S.s Svalbardiceras spitzbergense

W.t Wasatchites tardus

X.s Xenoceltites spitsbergensis

$\begin{array}{ll}\text { 1. Hammer new log } 2014 & \text { 2. Mørk et al. 1999b (fig. 13) }\end{array}$

3. Vigran et al. 2014 (fig. 37a)

Figure 2. Litho- and biostratigraphy at Marmierfjellet. Parts modified from Mørk et al. (1999b) and Vigran et al. (2014). 


\section{Vendomdalen Member}

The Vendomdalen Member is the uppermost of three members in the Lower Triassic Vikinghøgda Formation (Fig. 2), which is overlain by the Botneheia Formation (Mørk et al., 1999b). The depositional environment is interpreted to be distal shelf, below wave base, with a high accumulation of organic material in a low oxic environment (Mørk et al., 1999b). The member represents a transgressive sequence, observed by a reduction in terrestrial palynodebris, increase in marine plankton, decreased sedimentation rate and current indicators (Mørk et al., 1999b). It is characteristically defined by its $94 \mathrm{~m}$-thick transgression sequence at Vikinghøgda, consisting of dark grey, silty, laminated mudstone, together with yellow weathering dolomite nodules and beds (Mørk et al., 1999b).

At the mountain Vikinghøgda (Fig. 1), the Vendomdalen Member has been dated by ammonoids to be of Spathian age by Mørk et al. (1999b), where the lower part is identified as the Bajarunia euomphala Zone, above this the Parasibirites grambergi Zone, and the upper part as the Keyserlingites subrobustus Zone. The Spathian ammonoid zones are poorly resolved in the Boreal Ocean, but the Bajarunia euomphala Zone should be of earliest Spathian age while the Parasibirites grambergi Zone is of early to middle Spathian age. The Keyserlingites subrobustus Zone is late Spathian in age (Jenks et al., 2015). The section is also dated with palynomorphs by Vigran et al. (2014), where the lower part of the section is assigned to the Pechorosporites disertus Composite Assemblage Zone, early Spathian age, and the upper part to the Jerseyiaspora punctispinosa Composite Assemblage Zone of late Spathian age. Conodonts have been recovered throughout the Lower and Middle Triassic of Spitsbergen; however, they are sparse in the Spathian succession of both Svalbard and Arctic Canada. Nakrem et al. (2008) described four conodont collections from the upper part of the Vendomdalen Member at Milne Edwardsfjellet, sampled at 31, 48, 49.1 and $54.4 \mathrm{~m}$ above the base of the member. These levels concur with the range of the Keyserlingites subrobustus Zone, and an occurrence of Keyserlingites subrobustus was reported $36 \mathrm{~m}$ above the base of the member (Nakrem et al., 2008). So far, no conodonts older than the Keyserlingites subrobustus Zone are known from the Spathian Stage in Canada or Svalbard (Nakrem et al., 2008), and palynomorphs from the Vikinghøgda type sections are generally poorly preserved (Mørk et al., 1999b). The biostratigraphy of the Vendomdalen Member was correlated to magnetostratigraphy by Hounslow et al. (2008a). Hounslow et al. (2008b) further constructed a biomagnetostratigraphy for the Vikinghøgda Formation using the ammonoid biostratigraphy of the Arctic Boreal successions. Later, Hounslow \& Muttoni (2010) correlated the Early Triassic strata of Svalbard with other Triassic sections globally. The Vendomdalen Member shows mostly normal polarity, with two polarity reversals that allowed for close correlation to other Spathian sections of the Boreal Lower Triassic (Hounslow et al., 2008b).

The Vendomdalen Member at Marmierfjellet is approximately 39 metres thick and contains the vertebrate-bearing Grippia niveau and the Lower Saurian niveau (Fig. 2). The thickness at Marmierfjellet is comparable to nearby Ledalen (Vindodden), to one section at Stensiöfjellet in Sassendalen, and to Roslagenfjellet, East Spitsbergen, but is considerably thinner than at Vikinghøgda $(94 \mathrm{~m})$ and Milne Edwardsfjellet in Sassendalen (Vigran et al., 2014). This considerable thickness variation may be due to true lateral variation in sedimentation rate, and/or tectonic disturbance (especially thrust faults), and may complicate stratigraphic correlation. The carbonate beds consist either of calcite or dolomite, or a combination of these minerals. Some beds are formed mainly by flattened nodules or concretions, the latter of which are often septarian concretions. The beds are typically $5-20 \mathrm{~cm}$ thick and yellow-weathering; and these yellowweathering horizons make the Vendomdalen Member distinct from the lower members of the Vikinghøgda Formation (Mørk et al., 1999b). The upper siltstone bed is rich in ammonoids, with Keyserlingites subrobostus and Svalbardiceras spitsbergense in limestone concretions (Hounslow et al., 2008a; Weitschat, 2008).

\section{Botneheia Formation}

A possible transgressive event marks the boundary between the Vikinghøgda and Botneheia formations, and the upper sequence of the Botneheia Formation represents a moderately deep shelf environment, with distal deltaic lobes (Vigran et al., 2014). The formation is divided into the Anisian Muen Member and the Ladinian Blanknuten Member (Krajewski, 2008; Vigran et al., 2014). Dark, organic-rich shales with an abundance of phosphate nodules, infracted by alternating layers of bioturbation, characterise the formation (Lundschien et al., 2014; Vigran et al., 2014). As such, the depositional environment was mainly anoxic with short oxic periods (Vigran et al., 2014). An ammonoid zonation of the section has been produced (Weitschat \& Lehmann, 1983), and correlated to the recent palynozonation (fig. 3a in Vigran et al., 2014) with the Indigirites tozeri zone as Upper Ladinian, the Tsvetkovites varius zone Lower Ladinian and the Frechites laqueatus zone as Upper Anisian. The Indigirites tozeri ammonoid zone (Weitschat \& Lehmann, 1983) was correlated to the Blanknuten Member by Hounslow et al. (2008b).

The Upper Saurian niveau is situated in the Blanknuten Member bordered by the Muen Member below and the Tschermarkfjellet Formation above. The member is characterised by black shale and siltstone deposits with carbonate cementation, and an abundance of the bivalve Daonella (Weitschat \& Lehmann, 1983; Vigran et al., 2014). Typically, the ichthyopterygians found in the Upper Saurian niveau are embedded in the 
Daonella Shales. The preservation of ichthyopterygians is documented in at least the upper 10 metres of the formation.

\section{Conclusions}

Although the palaeontology of the Lower to Middle Triassic succession in Spitsbergen has been studied for more than a century and a half, recent fieldwork has demonstrated that there is still much to discover. However, our ability to properly interpret the evolutionary and ecological implications of the faunas requires precise stratigraphic control that has only recently become available. Within such a detailed stratigraphic framework, the Spitsbergen material promises to contribute to our understanding of the faunal recovery after the end-Permian mass extinction, the early evolution of Ichtyopterygia, the dynamics of the Smithian-Spathian turnover event and the marine palaeobiogeography and palaeoecology of the Boreal Triassic.

Acknowledgements. All necessary permits were obtained from the Governor of Svalbard for the excavations and fieldwork in 2014-2016. Permits no. RiS 6725, 2013/1222-2; RiS 10227, 2015/00326-2; RiS 10539, 2015/00326-5. Thanks to Spitsbergen Travel, National Geographic (grants GEFNE158-15; GEFNE 108-14), Bayerngas Norge, Tullow Oil and CGG for financing fieldwork in 2014-16. A special thanks to all volunteers (Øyvind Enger, Stig Larsen, Tommy Wensås, Magne Høyberget, Lena Kristiansen), technician (Biørn Lund), other staff (Charlotte Sletten Bjorå and Achim Reisdorf) and students (Tanja Wintrich, Ole Frederik Roaldset) who participated in some or all three field seasons. Large thanks to May-Liss Knudsen Funke from all students for supervision during preparation of the Triassic fossils. Thanks to reviewer Jan Stenløkk for constructive comments.

\section{References}

Beauchamp, B. \& Baud, A. 2002: Growth and demise of Permian biogenic chert along northwest Pangea: evidence for endPermian collapse of thermohaline circulation. Palaeogeography, Palaeoclimatology, Palaeoecology 184, 37-63.

https://doi.org/10.1016/S0031-0182(02)00245-6.

Benton, M.J. 1995: Diversification and extinction in the history of life. Science 268(5207), 52-58. https://doi.org/10.1126/science.7701342.

Benton, M.J., Zhang, Q., Hu, S., Chen, Z.-Q., Wen, W., Liu, J., Huang, J., Zhou, C., Xie, T., Tong, J. \& Choo, B. 2013: Exceptional vertebrate biotas from the Triassic of China, and the expansion of marine ecosystems after the Permo-Triassic mass extinction. Earth-Science Reviews 125, 199-243.

https://doi.org/10.1016/j.earscirev.2013.05.014.

Birkenmajer, K. 1977: Triassic sedimentary formations of the Hornsund area, Spitsbergen. Studia Geologica Polonica 51, 7-74.

Blomeier, D. 2015: Historical geology, Permian. In Dallmann, W.K. (ed.): Geoscience Atlas of Svalbard, Norsk polarinstitutt, Tromsø rapportserie 148, pp. 110-113.

Böhm, J. 1912: Über triasversteinerungen vom Bellsunde auf Spitzbergen. Kungliga Svenska Vetenskapsakademien, Almquist and Wiksells Boktryckeri-A.-B., Stockholm, 15 pp.
Bratvold, J., Delsett, L.L. \& Hurum, J.H. 2018: Chondrichthyans from the Grippia bonebed (Early Triassic) of Marmierfjellet, Spitsbergen. Norwegian Journal of Geology 98, 189-217. https://dx.doi.org/10.17850/njg98-2-03.

Brayard, A., Krumenacker, L.J., Botting, J.P., Jenks, J.F., Bylund, K.G., Fara, E., Vennin, E., Olivier, N., Goudemand, N., Saucède, T., Charbonnier, S., Romano, C., Doguzhaeva, L., Thuy, B., Hautmann, M., Stephen, D.A., Thomazo, C. \& Escarguel, G. 2017: Unexpected Early Triassic marine ecosystem and the rise of the Modern evolutionary fauna. Science Advances 3, e1602159. https://doi.org/10.1126/sciadv.1602159.

Buchan, S., Challinor, A., Harland, W. \& Parker, J. 1965: The Triassic stratigraphy of Svalbard. Norsk Polarinstitutt Skrifter 135, Oslo, 1-92.

Burgess, S.D., Muirhead, J.D. \& Bowring, S.A. 2017: Initial pulse of Siberian Traps sills as the trigger of the end-Permian mass extinction. Nature Communications 8:164. https://doi.org/10.1038/s41467-017-00083-9.

Dagys, A.S. \& Sobolev, E. 1995: Parastratotype of the Olenekian Stage (Lower Triassic). Albertiana 16, 8-16.

Dagys, A.S. \& Weitschat, W. 1993: Correlation of the Boreal Triassic. Mitteilungen aus dem Geologisch-Paläontologischen Institut der Universität Hamburg 75, 249-256.

Dallmann, W. K. (ed.) 2015. Geoscience Atlas of Svalbard. Norwegian Polar Instiute, Tromsø.

Dames, W.B. 1895: Über die Ichthyopterygier der Triasformation. Sitzungsberichte der Akademie der Wissenschaften zu Berlin 46, 1045-1050.

Diener, K. 1916: Die marinen Reiche der Triasperiode. Denkschriften der Kaiserlichen Akademie der Wissenschaften in Wien 92, 405-549.

Ekeheien, C.P., Delsett, L.L., Roberts, A.J. \& Hurum, J.H. 2018: Preliminary report on ichthyopterygian elements from the Early Triassic (Spathian) of Spitsbergen. Norwegian Journal of Geology 98, 219-237. https://dx.doi.org/10.17850/njg98-2-07.

Elewa, A.M.T. 2008: Mass Extinction. Springer, Dordrecht, Germany, $252 \mathrm{pp}$.

Engelschiøn, V.S., Delsett, L.L., Roberts, A.J. \& Hurum, J.H. 2018: Large-sized ichthyosaurs from the Lower Saurian niveau of the Vikinghøgda Formation (Early Triassic), Marmierfjellet, Spitsbergen. Norwegian Journal of Geology 98, 239-265. https:// dx.doi.org/10.17850/njg98-2-05.

Erwin, D.H. 1994: The Permo-Triassic extinction. Nature 367, 231-236. https://doi.org/10.1038/367231a0.

Erwin, D.H. 1998: The end and the beginning: recoveries from mass extinctions. Trends in Ecology and Evolution 13,344-349. https://doi.org/10.1016/S0169-5347(98)01436-0.

Foster, W.J., Silvia, D. \& Twitchett, R.J. 2016: A silicified Early Triassic marine assemblage from Svalbard. Journal of Systematic Palaeontology 15, 851-877. https://doi.org/10.1080/14772019.2016.1245680.

Frebold, H. 1930: Die Altersstellung des Fischhorizontes, des Grippianiveaus und des unteren Saurierhorizontes in Spitzbergen. Norsk Polarinstitutt Skrifter 28, 1-52.

Galfetti, T., Bucher, H., Ovtcharova, M., Schaltegger, U., Brayard, A., Brühwiler, T., Goudemand, N., Weissert, H., Hochuli, P.A., Cordey, F. \& Guodun, K. 2007: Timing of the Early Triassic carbon cycle perturbations inferred from new U-Pb ages and ammonoid biochronozones. Earth and Planetary Science Letters 258, 593-604. https://doi.org/10.1016/j.epsl.2007.04.023.

Hallam, A. \& Wignall, P.B. 1997: Mass Extinctions and Their Aftermath. Oxford University Press, New York, 320 pp.

Hansen, B.B., Hammer, Ø. \& Nakrem, H.A. 2018: Stratigraphy and age of the Grippia niveau bonebed, Lower Triassic Vikinghøgda Formation, Spitsbergen. Norwegian Journal of Geology 98, 175-187. https://dx.doi.org/10.17850/njg98-2-02.

Hounslow, M.W. \& Muttoni, G. 2010: The geomagnetic polarity timescale for the Triassic: linkage to stage boundary definitions. Geological Society of London Special Publications 334, 61-102. https://doi.org/10.1144/SP334.4. 
Hounslow, M.W., Peters, C., Mørk, A., Weitschat, W. \& Vigran, J.O. 2008a: Biomagnetostratigraphy of the Vikinghøgda Formation, Svalbard (Arctic Norway), and the geomagnetic polarity timescale for the Lower Triassic. Geological Society of America Bulletin 120, 1305-1325. https://doi.org/10.1130/B26103.1.

Hounslow, M.W., Hu, M., Mørk, A., Weitschat, W., Vigran, J.O., Karloukovski, V. \& Orchard, M.J. 2008b: Intercalibration of Boreal and Tethyan time scales: the magnetobiostratigraphy of the Middle Triassic and the latest Early Triassic from Spitsbergen, Arctic Norway. Polar Research 27, 469-490. https://doi.org/10.1111/j.1751-8369.2008.00074.x.

Hulke, J.W. 1873: Memorandum on Some Fossil Vertebrate Remains Collected by the Swedisch Expeditions to Spitzbergen in 1864 and 1868. Bihang till Kongliga Svenska Vetenskaps-Akademiens Handlingar 1, 2-11.

Hurum, J.H., Roberts, A.J., Nakrem, H.A., Stenløkk, J.A. \& Mørk, A. 2014: The first recovered ichthyosaur from the Middle Triassic of Edgeøya, Svalbard. Norwegian Petroleum Directorate Bulletin 11, 97-110.

Jenks, J.F., Monnet, C., Balini, M., Brayard, A. \& Meier, M. 2015: Biostratigraphy of Triassic Ammonoids. In Klug, C., Korn, D., De Baets, K., Kruta, I. \& Mapes, R.H. (eds.): Ammonoid Paleobiology: From macroevolution to paleogeography, Topics in Geobiology 44, pp. 329-388. https://doi.org/10.1007/978-94-017-9633-0_13.

Jiang, D.-Y., Motani, R., Huang, J.-D., Tintori, A., Hu, Y.-C., Rieppel, O., Fraser, N.C., Ji, C., Kelley, N.P., Fu, W.-L. \& Zhang, R. 2016: A large aberrant stem ichthyosauriform indicating early rise and demise of ichthyosauromorphs in the wake of the end-Permian extinction. Scientific Reports 6, 1-9. https://doi.org/10.1038/srep26232.

Kelley, N.P., Motani, R., Embree, P. \& Orchard, M.J. 2016: A new Lower Triassic ichthyopterygian assemblage from Fossil Hill, Nevada. PeerJ 4, e1626. https://doi.org/10.7717/peerj.1626.

Krajewski, K.P. 2008: The Botneheia Formation (Middle Triassic) in Edgeøya and Barentsøya, Svalbard: lithostratigraphy, facies, phosphogenesis, paleoenvironment. Polish Polar Research 29,319-364.

Krajewski, K.P., Karcz, P., Wozny, E. \& Mørk, A. 2007: Type section of the Bravaisberget Formation (Middle Triassic) at Bravaisberget, western Nathorst Land, Spitsbergen, Svalbard. Polish Polar Research $28,79-122$.

Lock, B., Pickton, C., Smith, D., Batten, D. \& Harland, W. 1978: The geology of Edgeøya and Barentsøya, Svalbard. Norsk Polarinstitutt Skrifter 168, 1-66.

Lundschien, B.A., Høy, T. \& Mørk, A. 2014: Triassic hydrocarbon potential in the Northern Barents Sea; integrating Svalbard and stratigraphic core data. Norwegian Petroleum Directorate Bulletin 11, 3-20.

Maisch, M.W. \& Blomeier, D. 2009: Filling the gap; an ichthyosaur (Reptilia: Ichthyosauria) from the Middle Triassic Botneheia Formation of Svalbard. Neues Jahrbuch für Geologie und Paläontologie - Abhandlungen 254, 379-384. https://doi.org/10.1127/0077-7749/2009/0014.

Maisch, M.W. \& Matzke, A.T. 2002a: Observations on Triassic ichthyosaurs. Part IX. The first associated skeletal remains of Merriamosaurus n.g. (Ichthyosauria, Lower Triassic) and their bearing on the systematic position of the Omphalosauria. Neues Jahrbuch für Geologie und Paläontologie Abhandlungen 226, 59-94.

Maisch, M.W. \& Matzke, A.T. 2002b: The skull of a large Lower Triassic ichthyosaur from Spitzbergen and its implications for the origin of the Ichthyosauria. Lethaia 35, 250-256. https://doi.org/10.1111/j.1502-3931.2002.tb00082.x.

Maisch, M.W. \& Matzke, A.T. 2003a: Observations on Triassic ichthyosaurs. Part X: The Lower Triassic Merriamosaurus from Spitzbergen - additional data on its anatomy and phylogenetic position. Neues Jahrbuch für Geologie und Paläontologie Abhandlungen 227, 93-137. https://doi.org/10.1127/njgpa/227/2003/93.

Maisch, M.W. \& Matzke, A.T. 2003b: Observations on Triassic ichthyosaurs. Part XII. A new Early Triassic ichthyosaur genus from Spitzbergen. Neues Jahrbuch für Geologie und Paläontologie Abhandlungen 229, 317-338.

https://doi.org/10.1127/njgpa/229/2003/317.
Massare, J.A. \& Callaway, J.M. 1994: Cymbospondylus (Ichthyosauria, Shastasauridae) from the Lower Triassic Thaynes Formation of Southeastern Idaho. Journal of Vertebrate Paleontology 14, 139-141. https://doi.org/10.1080/02724634.1994.10011545.

Maxwell, E.E. \& Kear, B.P. 2013: Triassic ichthyopterygian assemblages of the Svalbard archipelago: a reassessment of taxonomy and distribution. Journal of the Geological Society of Sweden 135, 85-94. https://doi.org/10.1080/11035897.2012.759145.

Mazin, J.-M. 1981a: Grippia longirostris Wiman, 1929, un Ichthyopterygia primitif du Trias inférieur du Spitsberg. Bulletin $d u$ Muséum National d'Histoire Naturelle 4, 317-340.

Mazin, J.-M. 1981b: Svalbardosaurus crassidens ng sp., un Ichthyopterygien nouveau du Spathien (Trias inférieur) du Spitsberg. Comptes Rendus de l'Académie des Sciences 293, 203-205.

Mazin, J.-M. 1983: Omphalosaurus nisseri (Wiman, 1910), un ichthyoptérygien à denture broyeuse du Trias moyen du Spitsberg. Bulletin du Muséum national d'histoire naturelle. Section C, Sciences de la terre, paléontologie, géologie, minéralogie 5, 243-263.

Mazin, J.-M. 1984: Les Ichthyopterygia du Trias du Spitsberg. Descriptions complémentaires à partir d`un nouveau matériel. Bulletin du Muséum national d'histoire naturelle. Section C, Sciences de la terre, paléontologie, géologie, minéralogie 6, 309-320.

Metcalfe, I. \& Isozaki, Y. 2009: Current perspectives on the PermianTriassic boundary and end-Permian mass extinction: Preface. Journal of Asian Earth Sciences 36, 407-412. https://doi.org/10.1016/j.jseaes.2009.07.009.

Mojsisovics, E.V. 1886: Arktische Triasfaunen. Beiträge zur paläontologischen Charakteristik der Arktisch-Pacifischen Triasprovinz. Mémoires de l'Académie Impériale des Sciences de St. Petersburg Séries 7.33 (6), 1-159.

Motani, R. 1999: Phylogeny of the Ichthyopterygia. Journal of Vertebrate Paleontology 19, 473-496. https://doi.org/10.1080/02724634.1999.10011160.

Motani, R. 2005: Evolution Of Fish-Shaped Reptiles (Reptilia: Ichthyopterygia) In Their Physical Environments And Constraints. Annual Review of Earth and Planetary Sciences 33, 395-420. https://doi.org/10.1146/annurev.earth.33.092203.122707.

Motani, R., Jiang, D.-Y., Chen, G.-B., Tintori, A., Rieppel, O., Ji, C. \& Huang, J.-D. 2014: A basal ichthyosauriform with a short snout from the Lower Triassic of China. Nature 517, 485-488. https://doi.org/10.1038/nature13866.

Mørk, A. 2015: Historical geology: the Triassic. In Dallmann, W.K. (ed.): Geoscience Atlas of Svalbard, Norsk polarinstitutt, Tromsø rapportserie 148, pp. 114-117.

Mørk, A., Knarud, R. \& Worsley, D. 1982: Depositional and diagenetic environments of the Triassic and Lower Jurassic succession of Svalbard. Arctic Geology and Geophysics: Proceedings of the Third International Symposium on Arctic Geology Memoir 8, 371-398.

Mørk, A., Vigran, J.O. \& Hochuli, P.A. 1990: Geology and palynology of the Triassic succession of Bjørnøya. Polar Research 8, 141-163. https://doi.org/10.3402/polar.v8i2.6810.

Mørk, A., Dallmann, W.K., Dypvik, H., Johannessen, E., Larssen, G., Nagy, J., Nøttvedt, A., Olaussen, S., Pčelina, T.M. \& Worsley, D. 1999a: Mesozoic lithostratigraphy. In Dallmann, W.K. (ed.): Lithostratigraphic lexicon of Svalbard: Upper Palaeozoic to Quaternary bedrock. Review and recommendations for nomenclatural use, Norsk polarinstitutt, Tromsø, pp. 127-214.

Mørk, A., Elvebakk, G., Forsberg, A.W., Hounslow, M.W., Nakrem, H.A., Vigran, J.O. \& Weitschat, W. 1999b: The type section of the Vikinghøgda Formation: a new Lower Triassic unit in central and eastern Svalbard. Polar Research 18, 51-82. https://doi.org/10.1111/j.1751-8369.1999.tb00277.x.

Nabbefeld, B., Grice, K., Twitchett, R.J., Summons, R.E., Hays, L., Böttcher, M.E. \& Asif, M. 2010: An integrated biomarker, isotopic and palaeoenvironmental study through the late Permian event at Lusitaniadalen, Spitsbergen. Earth and Planetary Science Letters 291, 84-96. https://doi.org/10.1016/j.epsl.2009.12.053. 
Nakrem, H.A., Orchard, M.J., Weitschat, W., Hounslow, M.W., Beatty, T.W. \& Mørk, A. 2008: Triassic conodonts from Svalbard and their Boreal correlations. Polar Research 27, 523-539. https://doi.org/10.1111/j.1751-8369.2008.00076.x.

Noetling, F. 1905: Die Asiatische Trias. Lethaea geognostica Teil II, Bd. I, Lieferung 2, 107-221.

Nordenskiöld, A.E. 1866: Utkast till Spetsbergens geologi. Kongliga Svenska Vetenskaps-Akademiens Handlingar 6, 1-35.

Nystuen, J.P.M., Müller, R., Mørk A. \& Nøttvedt, A. 2013: Fra ørken til elveslette - fra land til hav. Trias; 252-201 millioner år (chapter 10). In Ramberg, I.B., Bryhni, I., Nøttvedt, A. \& Rangnes, K. (eds.): Landet blir til: Norges geologi, Norsk Geologisk Forening, pp. 332357.

Pčelina, T.M. 1980: Novye dannye po pogranicnym slojam triasa i jury na arhipelage Sval'bard. Geologija osadocnogo cehla arhipelaga Sval'bard. Sbornik naucnyh trudov. Geologija osadocnogo cehla arhipelage Sval'bard, 4-60.

Pčelina, T.M. 1983: Novye dannye po stratigrafii mezozoja arhipelaga Špicbergen. In Krasil’ščikov, A.A. \& Basov, V.A. (eds.): Geologija Špicbergena, PGO Sevmorgeologija, Leningrad, pp. 121-141.

Piazza, V., Hammer, Ø. \& Jattiot. R. 2017: New late Smithian (Early Triassic) ammonoids from the Lusitaniadalen Member, Vikinghøgda Formation. Norwegian Journal of Geology 97, 105-117. https://dx.doi.org/10.17850/njg97-2-03.

Raup, D.M. \& Sepkoski, J.J. 1982: Mass Extinctions in the Marine Fossil Record. Science 215:4539, 1501-1503. https://doi.org/10.1126/science.215.4539.1501.

Riis, F., Lundschien, B.A., Høy, T., Mørk, A. \& Mørk, M.B.E. 2008: Evolution of the Triassic shelf in the northern Barents Sea region. Polar Research 27, 318-338. https://doi.org/10.1111/j.1751-8369.2008.00086.x.

Roopnarine, P.D. \& Angielczyk, K.D. 2015: Community stability and selective extinction during the Permian-Triassic mass extinction. Science 350:6256, 90-93. https://doi.org/10.1126/science.aab1371.

Sander, P.M. 2000: Ichthyosauria: their diversity, distribution, and phylogeny. Paläontologische Zeitschrift 74, 1-35. https://doi.org/10.1007/BF02987949.

Sander, P.M. \& Faber, C. 1998: New finds of Omphalosaurus and a review of Triassic ichthyosaur paleobiogeography. Paläontologische Zeitschrift 72, 149-162. https://doi.org/10.1007/BF02987823.

Scheyer, T.M., Romano, C., Jenks, J. \& Bucher, H. 2014: Early Triassic Marine Biotic Recovery: The Predators' Perspective. Plos One 9, e88987. https://doi.org/10.1371/journal.pone.0088987.

Spath, L.F. 1921: On Ammonites from Spitsbergen. Geological Magazine 58, 347-356. https://doi.org/10.1017/S0016756800104662.

Spath, L.F. 1934: Catalogue of the Fossil Cephalopoda in the British Museum (Natural History). Part 4: The Ammonoidea of the Trias. The Trustees of the British Museum, London, $42 \mathrm{pp}$.

Stensiö, E.A. 1918: Notes on some fish remains collected at Hornsund by the Norwegian Spitzbergen Expedition in 1917. Norsk Geologisk Tidsskrift 5, 75-78.

Stensiö, E.A. 1921: Triassic fishes from Spitzbergen, pt. 1. Adolf Holzhausen, Vienna, 341 pp.

Stensiö, E.A. 1925: Triassic fishes from Spitzbergen, Part 2. Kungliga Svenska Vetenskapsakademiens Handlingar Serie 3, vol. 2 nr. 1, $1-261$.

Stolley, E. 1911: Zur Kenntnis der arktischen Trias. Neues Jahrbuch für Geologie und Palaeontologie Abhandlungen Bd. I, 114-126.

Tozer, E.T. 1994: Canadian Triassic Ammonoid Faunas. Geological Survey of Canada Bulletin 467, 1-669. https://doi.org/10.4095/194325.

Tozer, E. \& Parker, J. 1968: Notes on the Triassic biostratigraphy of Svalbard. Geological Magazine 105, 526-542. https://doi.org/10.1017/S0016756800055886.

Vigran, J., Mangerud, G., Mørk, A., Worsley, D. \& Hochuli, P.A. 2014: Palynology and geology of the Triassic succession of Svalbard and the Barents Sea. Geological Survey of Norway Special Publication 14, 1-269.
Weitschat, W. 2008: Intraspecific variation of Svalbardiceras spitzbergensis (Frebold) from the Early Triassic (Spathian) of Spitsbergen. Polar Research 27, 292-297. https://doi.org/10.1111/j.1751-8369.2008.00041.x.

Weitschat, W. \& Dagys, A.S. 1989: Triassic biostratigraphy of Svalbard and a comparison with NE-Siberia. Mitteilungen aus dem Geologisch-Paläontologischen Institut der Universität Hamburg 68, 179-213.

Weitschat, W. \& Lehmann, U. 1978: Biostratigraphy of the uppermost part of the Smithian Stage (Lower Triassic) at the Botneheia, W-Spitsbergen. Mitteilungen aus dem Geologisch-Paläontologischen Institut der Universität Hamburg 48, 85-100.

Weitschat, W. \& Lehmann, U. 1983: Stratigraphy and ammonoids from the Middle Triassic Botneheia Formation (Daonella Shales) of Spitsbergen. Mitteilungen Geologisch-Paläontologisches Institut Universität Hamburg 54, 27-54.

Wignall, P.B., Morante, R. \& Newton, R. 1998: The Permo-Triassic transition in Spitsbergen: $\delta 13$ Corg chemostratigraphy, Fe and S geochemistry, facies, fauna and trace fossils. Geological Magazine 135, 47-62. https://doi.org/10.1017/S0016756897008121.

Wiman, C. 1910a: Ichthyosaurier aus der Trias Spitzbergens. Bulletin of the Geological Institution of the University of Uppsala 10, 124-148.

Wiman, C. 1910b: Ein Paar Labyrinthodontenreste aus der Trias Spitzbergens. Bulletin of the Geological Institution of the University of Uppsala 9, 33-41.

Wiman, C. 1914a: Ein Plesiosaurwirbel aus dem jungern Mesozoicum Spitsbergen. Bulletin of the Geological Institution of the University of Uppsala 12, 202-204.

Wiman, C. 1914b: Über die Stegocephalen aus der Trias Spitzbergens. Bulletin of the Geological Institution of the University of Uppsala 13, $1-34$.

Wiman, C. 1916a: Notes on the marine Triassic reptile fauna of Spitzbergen. Bulletin of the Geological Institution of the University of Uppsala 10,63-73.

Wiman, C. 1916b: Neue Stegocephalenfunde aus dem Posidonomyaschiefer Spitzbergens. Bulletin of the Geological Institution of the University of Uppsala 13, 13-30.

Wiman, C. 1917: Über die Stegocephalen Tertrema und Lonchorhyncus. Bulletin of the Geological Institution of the University of Uppsala 14, 15-29.

Wiman, C. 1918: Ein Archosaurier aus der Trias Spitzbergens. Bulletin of the Geological Institution of the University of Uppsala 16, 5-11.

Wiman, C. 1922: Über den Beckengürtel der Triasichthyosaurier. Palaeontologische Zeitschrift 5, 272-276. https://doi.org/10.1007/BF03160378.

Wiman, C. 1928: Eine neue marine Reptilien-Ordnung aus der Trias Spitzbergens. Bulletin of the Geological Institution of the University of Uppsala 22, 183-196.

Wiman, C. 1933: Über Grippia longirostris. Bulletin of the Geological Institution of the University of Uppsala 9, 1-24.

Worsley, D. 2008: The post-Caledonian development of Svalbard and the western Barents Sea. Polar Research 27, 298-317. https://doi.org/10.1111/j.1751-8369.2008.00085.x.

Worsley, D. \& Mørk, A. 1978: The Triassic stratigraphy of southern Spitsbergen. Norsk Polarinstitutt Årbok 1977, 43-60.

Yakowlew, N. von 1903: Neue Funde von Trias-Sauriern auf Spitzbergen. Zapiski Imperatoskago S. Peterburgskago mineralogicheskago obshchestva Ser 2, 40, 179-202.

Yin, H.F. \& Song, H.J. 2013: Mass extinction and Pangea integration during the Paleozoic-Mesozoic transition. Science China: Earth Sciences 56, 1791-1803. https://doi.org/10.1007/s11430-013-4624-3.

Økland, I.H., Delsett, L.L., Roberts, A.J. \& Hurum, J.H. 2018: A Phalarodon fraasi (Ichthyosauria: Mixosauridae) from the Middle Triassic of Svalbard. Norwegian Journal of Geology 98, 267-288, https://dx.doi.org/10.17850/njg98-2-06. 